\title{
The Long-Term Performance Consequences Of Strategic Partnerships In High Tech Industries
}

Carolyn M. Callahan, University of Memphis, USA

Rod E. Smith, California State University Long Beach, USA Angela Wheeler Spencer, Oklahoma State University, USA

\begin{abstract}
In this paper, we examine how inter-firm partnerships impact long-term operating performance. With a global economy, rapid product cycles, capital constraints and advances in technology, firms seldom possess all the capabilities necessary to maintain and grow market share. Consequently, firms rely on a variety of partnerships. Theory suggests that firms enter such relationships to improve performance through access to new products, new markets, or new capabilities. Yet, relatively little is known about the long-term impact of collaborative arrangements such as alliances and established major customer relationships, although such dual partnership arrangements can have a major impact on the firm's performance success. Our empirical results indicate that inter-firm partnerships affect operating performance, but the impact often depends on the industry, the nature of the firm, and the type of partnership.
\end{abstract}

Keywords: Alliances; Major Customer Relationships; FAS 131

\section{INTRODUCTION}

e investigate the effect of interfirm partnerships on the long-term performance of high-tech firms.
Seeking competitive advantage, today's managers often turn to such partnerships. These
relationships can provide new sources of growth while allowing firms to manage costs, rapid product cycles, capital constraints, and advances in technology (PriceWaterhouseCoopers, 2004; Alvarez and Barney, 2001). Yet, little is known about the long-term impact of interfirm partnerships on firm performance, and evidence indicates many managers are disappointed in partnership results (PriceWaterhouseCoopers, 2004).

Collaborative relationships encompass a variety of organizational forms. Chiesa and Manzini (1998) describe a continuum of collaborations specified by integration of activities and resources between firms: acquisitions lie at one end, outsourcing at the other, and varying long-term relationships such as joint ventures and strategic alliances lie in between. Interfirm partnerships can also be classified as either horizontal or vertical. Both augment firm internal resources through collaboration: horizontal partnerships do so with competing or unrelated firms and vertical partnerships with either suppliers or customers.

Horizontal partnerships - broadly referred to as alliances — have been studied extensively. Baker et al. (2002), define an alliance as any structure to manage an incomplete contract between separate firms, with limited individual partner control. Despite a sizeable body of research examining market reactions to alliances (e.g., Koh and Venkatraman, 1991; Das et al., 1998), relatively few studies examine their longer-term performance consequences. Further, Chan et al. (1997) find no evidence of performance improvement following alliance formation and Dyer et al. (2004) note that half of all alliances fail.

Vertical partnerships include supplier relationships with major customers, ranging from routine buyersupplier transactions to formal strategic alliances. The opportunity to share information and improve overall supply 
chain management creates the potential for performance improvements. However, Dwyer et al. (1987) note powerful customers can exploit that relationship and capture most of the potential rewards. Although U.S. accounting standards require that firms report major customer relationships (Financial Accounting Standard (FAS) 14, superseded by FAS 131), little is known about their impact on firm operating performance.

In this study, we examine the joint and several impacts of both major customer relationships and alliances on the operating performance of high-tech firms over the period 1988 to 2004. For this analysis, we first select all firms in designated high-tech industries (as defined in Francis and Schipper, 1999) and divide that sample into partnering and non-partnering firms based on whether the firm reports a major customer. We then further subdivide the partnering sub-sample based on whether those firms also announced alliances. We differentiate between research and marketing alliances and examine differences in the impact of alliances across high tech industries.

We find evidence that major customer relationships improve operating performance, but gains often depend on the industry and nature of the partnership. We note firms that report major customer relationships generally perform better than firms that never make such disclosure. Similarly, firms that announce marketing alliances generally perform better than firms that do not announce alliances, although performance seems to erode over time. Firms that announce research alliances perform below industry counterparts on average, and that performance changes little during the alliances. Consistent with prior alliance research, we also find that alliance announcements are generally met with positive market response, although the status of the major customer relationship and the type of alliance (marketing versus research) both temper market reaction. This investigation adds to the body of knowledge about both strategic alliances and major customer relationships and provides insight into the circumstances in which such partnerships create value for the firm. With many firms facing increasing competitive pressures and uncertain operating environments, these results may provide managers with greater insight into which arrangements grant firms the greatest potential for value creation.

\section{INTERFIRM PARTNERSHIPS AND FIRM PERFORMANCE}

Researchers broadly agree that firms enter partnerships to create and appropriate value. Arend and Amit (2005) note that firms engage in significant partnering activities based on their needs, opportunities, and incentives. For instance, firms seek to create value through partnerships by acquiring access to complementary resources that they do not possess (e.g., McConnell and Nantell, 1985; Alvarez and Barney, 2001) and to strengthen their competitive position (Eisenhardt and Schoonhoven, 1996). Smaller and younger firms also seek partnerships to create legitimacy (Alvarez and Barney, 2001). A relationship with larger, established partners signals information to security analysts (Jensen, 2004) as well as other potential partners and third parties, enabling young firms to attract capital not otherwise available (Stuart et al., 1999). Firms appropriate value from partnerships when they capture rents from increased growth through access to products (Koh and Venkatraman, 1991; Gomes-Casseres, 1997) and by reducing costs via increased operational efficiency (Harrigan, 1986; Dwyer and Oh, 1988).

Despite the potential for value creation, many partnerships are not successful. Kale et al. (2002) report that over half of alliances fail, and Dyer et al. (2004) show that alliances typically create very little wealth for shareholders. A number of possible reasons exist for this lack of success. For instance, larger firms may capture disproportionate shares of any value created in the partnership (Borys and Jemison, 1989; Alvarez and Barney, 2001) and partners may have different levels of investment and commitment to the relationship (Dwyer and Oh, 1988). As Dekker (2004) and Reuer and Leiblein (2000) discuss, partnerships create control issues. For example, joint control challenges occur because of increased organizational complexity, and because each partner has an imperfect claim to the opportunities created. Thus, the partners face two problems: 1) creating value through a partnership, and 2) capturing that value for themselves.

\section{Major customer relationships and firm performance}

FAS 14's stated purpose "to assist financial statement users in analyzing and understanding the enterprise's financial statements by permitting better assessment of the enterprise's past performance and future prospects" requires firms to disclose major customer relationships when "10 percent or more of the revenue of an enterprise is derived from sales to any single customer." This standard was superseded by FAS 131, but the major customer 
reporting requirement was retained. The underlying presumption is reliance on a major customer can affect future performance; thus disclosure is necessitated.

Although major customer relationships often take on the appearance of or become alliances, these relationships have received relatively little attention in academic literature, and the existing research focuses on the benefits to the customer firm. For example, Gosman et al. (2004) find that major retailing customer firms have significantly higher operating profitability, but they do not examine the impact of the buyer-supplier relationship on supplier performance. Ittner et al. (1999) find that the use of advanced supplier selection strategies enhances customer performance and operations when firms follow supplier partnership strategies. The supply chain management literature indicates that close ties between supplier and customer offer potential for sharing information and increasing operational efficiencies (e.g., Lambert, 2006).

In summary, major customer relationships offer potential for value creation but do not necessarily imply suppliers will realize benefits. We therefore test the following null hypothesis:

Hypothesis 1: High tech firms that enter a major customer relationship will not improve overall operating performance.

\section{Alliances and firm performance}

The academic literature has paid more attention to alliances. In general, prior results have shown that such partnerships tend to generate positive market reactions, indicating a perceived association between alliance formation and positive long-term performance changes. For example, Piachaud and Muresan (2004) and Gleason et al. (2003) observe positive market reactions to the announcement of alliances. Marciukaiyte, et al. (2009), however, do not find that such returns persist over time.

Alliance purpose also seems to influence market reaction. Koh and Venkatraman (1991) find information technology joint ventures have a positive effect if they strengthen existing operations, but not if they develop new customers or enter new, unrelated product-market segments. Das et al. (1998) found technological alliances generated greater abnormal returns than marketing alliances, seemingly because marketing alliances indicate that the product market is mature and/or declining. Son et al. (2006) however, find that alliances can offer benefits in mature product life cycles even if total demand does not grow. Additionally, Chan et al. (1997) find alliances involving a transfer or pooling of technical knowledge created greater value.

Financial health has also been found to influence the magnitude of the market reaction. Mohanram and Nanda (1998) found firms with high levels of free cash flow before joint venture announcements experienced a negative market reaction. Similarly, Das et al. (1998) found abnormal returns to be negatively correlated with profitability and size.

Bamford and Ernst (2002) argue managers must assess economic performance of partnerships over time. Despite the abundance of studies examining market expectations at alliance formation, relatively few studies have investigated whether those expectations were confirmed by long-term performance. For example, Chan et al. (1997) find little evidence alliances affect financial performance. Allen and Phillips (2000) find evidence of alliance performance benefits, but only in limited circumstances. Hagedoorn and Schakenraad (1994) were unable to show a direct relationship between strategic partnering and firm performance.

In summary, relatively little is known about the longer-term performance consequences of alliances, although the type of alliance may affect performance. We differentiate between research alliances, where the purpose of the alliance is specifically research and development $(R \& D)$, and marketing alliances, where the purpose of the alliance is to market an existing product, examining the following null hypotheses:

Hypothesis 2: High tech firms that enter formal alliances will not improve overall operating performance. 
Hypothesis 2a: High tech firms that enter formal research alliances will not improve overall operating performance.

Hypothesis 2b: High tech firms that enter formal marketing alliances will not improve overall operating performance.

\section{Alliances and major customer relationships combined}

Although some factors that impact the benefit of alliances are known, less is known about major customer relationships, and essentially nothing is known about the combined impact of the two. This study seeks to fill this gap by examining a group of high-tech firms that entered both major customer relationships and alliances. The combined impact holds special importance for this group of firms, since many are small and struggling financially while trying to succeed in highly competitive industries that demand substantial capital funding.

Further, as it appears governance structure (Lee and Cavusgil 2006), the complete alliance portfolio of a firm, relationship management (Beckett-Camarata, et al. 1998) and factors such as alliance experience contribute to positive partnership performance (Sarkar, Aulakh, and Madhok, 2009), the combined effect of alliances and major customer relationships may prove important. We therefore address the following null hypothesis:

Hypothesis 3: High tech firms that participate in both major customer relationships and alliances do not improve overall operating performance.

To test whether partnering arrangements individually or collectively enhance firm performance, we compare performance in partnering arrangements against two benchmarks: (1) Non-partnering firm performance within the same industries and (2) performance before those firms enter partnerships.

\section{SAMPLE SELECTION AND DESCRIPTION}

The sample comprises high-tech firms during the period 1988 to 2004. We use SIC codes from Francis and Schipper (1999, Table 5) to determine high-tech industries. Using Compustat, we first identify all firms in those SIC categories. We eliminate firms with zero or missing values for total sales revenue. From that initial sample, we then further identify those firms that reported major customer relationships for any year during that period in accordance with FAS 14 (superseded by FAS 131). For each firm reporting a major customer relationship, we then identified whether that firm announced its participation in any alliance (e.g., joint venture, licensing agreement) during the period.

We differentiate between research (purpose explicitly $R \& D$ ) and marketing (purpose explicitly to market an existing product) alliances due to obvious differences in fundamental risk. In marketing alliances, viable products usually already exist and firms are joining forces to expand the market. In research alliances, especially in the pharmaceutical and biotech industry, a viable product may never exist. Furthermore, prior research finds greater returns to research alliances (e.g., Koh and Venkatraman, 1991).

As Table 1 shows, pharmaceutical and biotech companies (SIC code 28) account for over $43 \%$ of the total high tech observations, $42 \%$ of the major customer relationships, $74 \%$ of the research alliances, and $58 \%$ of the marketing alliances. Computer and electronic manufacturers (SIC 35 and 36) collectively account for more than $50 \%$ of the observations, $53 \%$ of the major customer relationships, and $26 \%$ of the research alliances, and $42 \%$ of the marketing alliances. Business services (SIC 87) account for $5 \%$ of the observations and $6 \%$ of the major customer relationships, but none of the alliances. $78 \%$ of the firms in these high-tech industries reported major customer relationships at some time during the period 1988 to 2004, with $11.4 \%$ reporting some type of alliance.

To identify alliances, we searched the Wall Street Journal (on-line edition) for announcements of collaborative relationships. Since firms use a variety of terms to describe alliances, we used the broadest possible search, starting with only each firm's name. We then reviewed all available articles to find announcements of alliances. We identified 288 announcements as summarized in Table 1. Of those announcements, 54\% involved 
research alliances, where the purpose of the alliance was either basic research or product development. Approximately $26 \%$ involved marketing alliances, where companies agreed to collaborate on the marketing of an existing product or one company licenses its products to another company. The remainder of the announcements involved acquisitions, which represent the closest possible relationship on the continuum of interfirm partnerships described by Chiesa and Manzini (1998). As Table 1 reports, most of the alliance announcements occurred during the 1990s, increasing each year until 1994 and then generally decreasing until 2003. The proportion of firms with major customer relationships generally increased from $70 \%$ in 1988 to $83 \%$ in 2004.

\section{ANALYSIS OF PARTNERSHIPS AND FIRM PERFORMANCE}

\section{Measuring firm performance}

Contractor and Lorange $(1988,2004)$ argue firms engage in partnerships to increase revenues or reduce costs, producing higher return on assets (ROA), ceteris paribus. We therefore focus on operating ROA (defined as operating income before depreciation, divided by total assets) as an overall measure of firm performance. ROA provides a direct measure of overall performance not confounded by differences in capital structure among firms.

We also examine the impact of partnerships on $R \& D$ intensity, as $R \& D$ is both a source of potential competitive advantage and a major expense for high-tech firms. Managers in high tech firms seek to balance R\&D investment against the negative impact on bottom-line earnings (Wilbon, 2002; Standard and Poor's 2001). Since resource limitations may constrain firms' ability to conduct research, firms may seek access to capital and other resources through partnerships since shared resources may allow firms to expand their R\&D activities (e.g., McCutchen, Jr. and Swamidass, 2004). On the other hand, partnerships may reduce R\&D intensity. Sales growth through a major customer relationship could reduce $R \& D$ and shared research efforts with alliance partners could spread $R \& D$ costs over multiple firms.

\section{Univariate analysis of firm performance before and during partnerships}

\section{Operating ROA performance}

Table 2 summarizes operating ROA performance related to major customer relationships. As a benchmark, we adjust each firm's reported operating ROA by subtracting the median operating ROA for all firms not engaging in major customer relationships in the same industry (3 digit SIC) and year. We also present results for firms that we term survivors. These are firms that continue in operation from the year they go public until at least 2004. Wilbon (2002) argues survival is the ultimate performance measure in high tech industries.

For most of our sample, even before entering the partnership, firms that report major customer relationships have substantially higher median operating ROA than firms that never report such arrangements. After entering major customer relationships, median firm performance increases significantly for the pharmaceutical and biotech firms as well as the business services firms ( $\mathrm{p}<0.05$, Kruskal-Wallis test of equality of populations). The performance increase is more pronounced for survivor firms, especially in the pharmaceutical and biotech industry ( $\mathrm{p}<0.001$, Kruskal-Wallis test of equality of populations). Firms in the computer and electronics manufacturing industry, however, show little change in performance. Thus, null hypothesis 1 is not confirmed; firms improve performance during major customer relationships, although the results depend on the industry.

Table 3 summarizes operating ROA performance related to research or marketing alliances. Again, the results vary by industry. Prior to announcing research alliances, operating ROA is substantially below the benchmark for firms in the pharmaceutical and biotech industries, but operating ROA increases significantly after the alliance announcements ( $p<0.01$, Kruskal-Wallis test of equality of populations). Thus, the results are mixed; null hypotheses 2 and 2a are not confirmed for firms in the pharmaceutical and biotech industry as they do improve operating performance following research alliances. Firms in the computer and electronics manufacturing industry see no similar improvement. 
Table 1

Sample Characteristics Major Customer Relationship and Alliance Partnership Counts

\begin{tabular}{|c|c|c|c|c|c|c|}
\hline \multicolumn{3}{|c|}{ 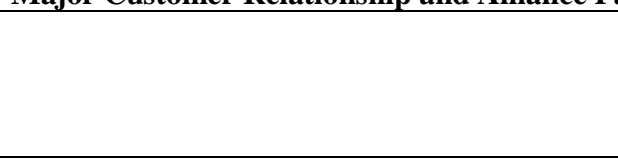 } & $\begin{array}{c}\text { Pharmaceuticals } \\
\text { and Biotech }\end{array}$ & $\begin{array}{c}\text { Computer, } \\
\text { Electronics and } \\
\text { Electrical } \\
\text { Manufacturing } \\
\end{array}$ & $\begin{array}{l}\text { Business } \\
\text { Services }\end{array}$ & Total \\
\hline \multicolumn{3}{|c|}{ All Available Firm-Year Observations ${ }^{\mathrm{a}}$} & 5,879 & 6,955 & 707 & 13,541 \\
\hline \multicolumn{3}{|c|}{ Report Major Customers ${ }^{b}$} & 4,398 & 5,547 & 614 & 10,559 \\
\hline \multicolumn{3}{|c|}{ Percent of All Available } & $74.80 \%$ & $79.76 \%$ & $86.80 \%$ & $78.00 \%$ \\
\hline \multirow{2}{*}{\multicolumn{3}{|c|}{$\begin{array}{l}\text { Report Research Alliance }{ }^{c} \\
\text { Percent of Firms Reporting Major Customers }\end{array}$}} & 518 & 184 & 0 & 702 \\
\hline & & & $11.80 \%$ & $3.32 \%$ & $0.00 \%$ & $6.60 \%$ \\
\hline \multirow{2}{*}{\multicolumn{3}{|c|}{$\begin{array}{l}\text { Report Marketing Alliance }^{c} \\
\text { Percent of Firms Reporting Major Customers }\end{array}$}} & 291 & 212 & 0 & 503 \\
\hline & & & $6.60 \%$ & $3.82 \%$ & $0.00 \%$ & $4.80 \%$ \\
\hline \multicolumn{7}{|c|}{ Count and value of announced alliances } \\
\hline & Type of Alliance & & Number of announcements & \multicolumn{2}{|c|}{$\begin{array}{c}\text { Value of } \\
\text { announcements } \\
(\$ \mathrm{~mm})\end{array}$} & $\begin{array}{l}\text { Value of acquisitions } \\
\qquad(\$ \mathrm{~mm})\end{array}$ \\
\hline & Research alliance & & 155 & \multicolumn{2}{|c|}{$\$ 4,719.2$} & $\$ 0.0$ \\
\hline & Marketing allianc & & 76 & \multicolumn{2}{|c|}{$\$ 2,328.1$} & $\$ 0.0$ \\
\hline & Acquisition & & 57 & \multicolumn{2}{|c|}{$\$ 74,418.3$} & $\$ 73,758.3$ \\
\hline & Total & & 288 & \multicolumn{2}{|c|}{$\$ 81,465.6$} & $\$ 73,758.3$ \\
\hline \multicolumn{7}{|c|}{ Distribution of partnerships by year } \\
\hline Year & $\begin{array}{c}\text { Number of } \\
\text { alliance } \\
\text { announcements }\end{array}$ & $\begin{array}{c}\text { Value of } \\
\text { announcements } \\
(\$ \mathrm{~mm})\end{array}$ & $\begin{array}{l}\text { Value of } \\
\text { acquisitions } \\
(\$ \mathrm{~mm})\end{array}$ & $\begin{array}{c}\text { Total } \\
\text { Number } \\
\text { of Firms }\end{array}$ & $\begin{array}{l}\text { Number of Firms } \\
\text { w/Major } \\
\text { Customer } \\
\text { Relationship }\end{array}$ & $\begin{array}{l}\text { Proportion of } \\
\text { Firms } \\
\text { w/Major } \\
\text { Customer } \\
\end{array}$ \\
\hline 1988 & 4 & $\$ 49.0$ & $\$ 0.0$ & 566 & 398 & $70 \%$ \\
\hline 1989 & 9 & $\$ 0.0$ & $\$ 0.0$ & 563 & 409 & $73 \%$ \\
\hline 1990 & 14 & $\$ 192.8$ & $\$ 0.0$ & 586 & 439 & $75 \%$ \\
\hline 1991 & 18 & $\$ 1,696.5$ & $\$ 520.0$ & 626 & 471 & $75 \%$ \\
\hline 1992 & 24 & $\$ 840.0$ & $\$ 810.0$ & 687 & 516 & $75 \%$ \\
\hline 1993 & 28 & $\$ 787.4$ & $\$ 450.0$ & 740 & 551 & $74 \%$ \\
\hline 1994 & 37 & $\$ 830.9$ & $\$ 539.6$ & 778 & 588 & $76 \%$ \\
\hline 1995 & 30 & $\$ 9,972.6$ & $\$ 9,603.6$ & 885 & 668 & $75 \%$ \\
\hline 1996 & 31 & $\$ 7,534.8$ & $\$ 6,800.5$ & 934 & 708 & $76 \%$ \\
\hline 1997 & 19 & $\$ 2,610.5$ & $\$ 1,886.0$ & 933 & 717 & $77 \%$ \\
\hline 1998 & 18 & $\$ 1,747.5$ & $\$ 1,053.0$ & 992 & 780 & $79 \%$ \\
\hline 1999 & 19 & $\$ 35,308.5$ & $\$ 34,856.0$ & 979 & 781 & $80 \%$ \\
\hline 2000 & 17 & $\$ 2,035.5$ & $\$ 1,282.5$ & 943 & 765 & $81 \%$ \\
\hline 2001 & 8 & $\$ 14,375.0$ & $\$ 13,290.0$ & 889 & 739 & $83 \%$ \\
\hline 2002 & 5 & $\$ 2,145.1$ & $\$ 2,037.1$ & 858 & 719 & $84 \%$ \\
\hline 2003 & 7 & $\$ 1,339.5$ & $\$ 630.0$ & 837 & 690 & $82 \%$ \\
\hline 2004 & 0 & $\$ 0.0$ & $\$ 0.0$ & 745 & 620 & $83 \%$ \\
\hline $\begin{array}{c}\text { Total } \\
\text { sample }\end{array}$ & 288 & $\$ 81,465.6$ & $\$ 73,758.3$ & 13,541 & 10,559 & $78 \%$ \\
\hline
\end{tabular}


Table 2

Median Operating Return on Assets (ROA) ${ }^{\text {a }}$ around the First Year of Major Customer Relationships (MCR) (with numbers of observations for each industry and year)

\begin{tabular}{|c|c|c|c|c|c|c|c|c|}
\hline \multirow[b]{3}{*}{$\begin{array}{c}\text { Year } \\
\text { Relative to } \\
\text { Start (0) of } \\
\text { MCR }\end{array}$} & \multicolumn{4}{|c|}{ All Available Observations } & \multicolumn{4}{|c|}{ Observations for Survivor ${ }^{\mathbf{b}}$ Firms } \\
\hline & \multicolumn{3}{|c|}{ Industry } & & \multicolumn{3}{|c|}{ Industry } & \multirow[b]{2}{*}{ Total } \\
\hline & $\begin{array}{l}\text { Pharma. } \\
\text { and } \\
\text { Biotech } \\
\text { (SIC 28) }\end{array}$ & $\begin{array}{c}\text { Computer, } \\
\text { Electronics } \\
\text { and Electrical } \\
\text { Mfg. } \\
\text { (SICs 35, 36) }\end{array}$ & $\begin{array}{l}\text { Business } \\
\text { Services } \\
\text { (SIC 87) }\end{array}$ & Total & $\begin{array}{l}\text { Pharma. } \\
\text { and } \\
\text { Biotech } \\
\text { (SIC 28) }\end{array}$ & $\begin{array}{c}\text { Computer, } \\
\text { Electronics } \\
\text { and Electrical } \\
\text { Mfg. } \\
\text { (SICs 35, 36) }\end{array}$ & $\begin{array}{l}\text { Business } \\
\text { Services } \\
\text { (SIC 87) }\end{array}$ & \\
\hline \multirow[t]{2}{*}{-3} & 0.123 & 0.012 & 0.363 & 0.051 & 0.160 & 0.020 & 0.363 & 0.065 \\
\hline & 275 & 295 & 30 & 600 & 181 & 191 & 22 & 394 \\
\hline \multirow[t]{2}{*}{-2} & 0.138 & 0.009 & 0.413 & 0.056 & 0.186 & 0.026 & 0.429 & 0.075 \\
\hline & 299 & 331 & 36 & 666 & 195 & 207 & 26 & 428 \\
\hline \multirow[t]{2}{*}{-1} & 0.131 & 0.004 & 0.397 & 0.044 & 0.181 & 0.025 & 0.440 & 0.071 \\
\hline & 326 & 363 & 43 & 732 & 213 & 222 & 28 & 63 \\
\hline \multirow[t]{2}{*}{0} & 0.108 & 0.019 & 0.424 & 0.057 & 0.177 & 0.036 & 0.458 & 0.105 \\
\hline & 427 & 480 & 64 & 971 & 257 & 262 & 37 & 556 \\
\hline \multirow[t]{2}{*}{1} & 0.136 & 0.022 & 0.475 & 0.074 & 0.199 & 0.047 & 0.494 & 0.110 \\
\hline & 388 & 445 & 60 & 893 & 240 & 259 & 37 & 536 \\
\hline \multirow[t]{2}{*}{2} & 0.181 & -0.011 & 0.355 & 0.055 & 0.233 & -0.003 & 0.402 & 0.082 \\
\hline & 343 & 410 & 57 & 810 & 225 & 254 & 37 & 516 \\
\hline 3 & 0.245 & 0.001 & 0.469 & 0.067 & 0.286 & 0.008 & 0.582 & 0.089 \\
\hline & 300 & 360 & 49 & 709 & 202 & 241 & 34 & 477 \\
\hline \multirow[t]{2}{*}{ Total } & 0.151 & 0.008 & 0.408 & 0.057 & 0.205 & 0.025 & 0.449 & 0.085 \\
\hline & 2,358 & 2,684 & 339 & 5,381 & 1,513 & 1,636 & 221 & 3,370 \\
\hline
\end{tabular}

${ }^{\mathrm{a}}$ Operating ROA (operating income divided by total assets) values adjusted by subtracting the median value for those firms that did not engage in major customer relationships or announce alliances within the same industry and year. ${ }^{\mathrm{b}}$ Firms with financial data on Compustat for every year since they first reported publicly available data.

Table 3

Median Operating Return on Assets (ROA) a around the First Year of Announced Alliances (with numbers of observations for each industry and year)

\begin{tabular}{|c|c|c|c|c|c|c|}
\hline \multirow[b]{3}{*}{$\begin{array}{c}\text { Year } \\
\text { Relative to } \\
\text { Start (0) of } \\
\text { Alliance }\end{array}$} & \multicolumn{3}{|c|}{ Research Alliances } & \multicolumn{3}{|c|}{ Marketing Alliances } \\
\hline & \multicolumn{2}{|c|}{ Industry } & \multirow[b]{2}{*}{ Total } & \multicolumn{2}{|c|}{ Industry } & \multirow[b]{2}{*}{ Total } \\
\hline & $\begin{array}{l}\text { Pharma. } \\
\text { and Biotech } \\
\text { (SIC 28) }\end{array}$ & $\begin{array}{l}\text { Computer, } \\
\text { Electronics and } \\
\text { Electrical Mfg. } \\
\text { (SICs 35, 36) }\end{array}$ & & $\begin{array}{l}\text { Pharma. } \\
\text { and Biotech } \\
\text { (SIC 28) }\end{array}$ & $\begin{array}{l}\text { Computer, } \\
\text { Electronics and } \\
\text { Electrical Mfg. } \\
\text { (SICs 35, 36) }\end{array}$ & \\
\hline \multirow[t]{2}{*}{-3} & -0.128 & 0.074 & -0.007 & 0.151 & 0.048 & 0.061 \\
\hline & 28 & 9 & 37 & 11 & 12 & 23 \\
\hline \multirow[t]{2}{*}{-2} & -0.059 & -0.044 & -0.051 & 0.085 & 0.047 & 0.053 \\
\hline & 33 & 15 & 48 & 15 & 15 & 30 \\
\hline \multirow[t]{2}{*}{-1} & -0.114 & 0.044 & -0.036 & 0.111 & 0.067 & 0.074 \\
\hline & 40 & 15 & 55 & 20 & 17 & 37 \\
\hline \multirow[t]{2}{*}{0} & -0.016 & -0.036 & -0.016 & 0.111 & -0.003 & 0.054 \\
\hline & 51 & 17 & 68 & 24 & 17 & 41 \\
\hline \multirow[t]{2}{*}{1} & -0.011 & 0.001 & -0.005 & 0.169 & -0.004 & 0.049 \\
\hline & 49 & 17 & 66 & 24 & 18 & 42 \\
\hline \multirow[t]{2}{*}{2} & -0.025 & -0.023 & -0.025 & 0.130 & 0.011 & 0.026 \\
\hline & 44 & 16 & 60 & 22 & 16 & 38 \\
\hline \multirow[t]{2}{*}{3} & 0.123 & 0.001 & 0.033 & 0.167 & -0.061 & 0.052 \\
\hline & 39 & 13 & 52 & 21 & 16 & 37 \\
\hline \multirow[t]{2}{*}{ Total } & -0.023 & -0.008 & -0.017 & 0.113 & 0.006 & 0.053 \\
\hline & 284 & 102 & 386 & 137 & 111 & 248 \\
\hline
\end{tabular}

\footnotetext{
${ }^{a}$ Operating ROA (operating income divided by total assets) values adjusted by subtracting the median value for those firms that
} did not engage in major customer relationships or announce alliances within the same industry and year. 
Both before and after marketing alliance announcements, firms in the pharmaceutical and biotech industry substantially outperform the benchmark, but the increase in performance is not significant. Again, performance does not significantly improve for firms in the computer and electronics manufacturing industry. Thus, the null hypothesis $(2 b)$ is confirmed for both industries.

\section{Research and Development intensity ( $R \& D /$ Sales Ratio) performance}

Table 4 summarizes R\&D intensity around the start of major customer relationships. The results are again mixed with patterns similar to those shown in Table 2. Pharmaceutical and biotech and business service firms have substantially lower R\&D intensity than the benchmark both before and after major customer relationships. For these firms, R\&D intensity decreases significantly after entering major customer relationships $(\mathrm{p}<0.01$, Kruskal-Wallis test of equality of populations), and the results are more pronounced for survivor firms ( $p<0.0001$, Kruskal-Wallis test). These results cause rejection of null hypothesis 1 . For firms in the computer and electronics manufacturing industry, however, $R \& D$ intensity is similar to the benchmark firms and does not significantly change after starting the customer relationship.

Table 4

Median R\&D Intensity a around the First Year of Reported Major Customer Relationships (MCR) (with numbers of observations for each industry and year)

\begin{tabular}{|c|c|c|c|c|c|c|c|c|}
\hline \multirow[b]{3}{*}{$\begin{array}{c}\text { Year Relative } \\
\text { to Start (0) of } \\
\text { MCR }\end{array}$} & \multicolumn{4}{|c|}{ All Available Observations } & \multicolumn{4}{|c|}{ Observations for Survivor Firms } \\
\hline & \multicolumn{3}{|c|}{ Industry } & \multirow[b]{2}{*}{ Total } & \multicolumn{3}{|c|}{ Industry } & \multirow[b]{2}{*}{ Total } \\
\hline & $\begin{array}{c}\text { Pharm } \\
\text { a. and } \\
\text { Biotech }\end{array}$ & $\begin{array}{c}\text { Computer, } \\
\text { Electronics } \\
\text { Mfg. } \\
\end{array}$ & $\begin{array}{l}\text { Business } \\
\text { Services } \\
\end{array}$ & & $\begin{array}{l}\text { Pharma. } \\
\text { and } \\
\text { Biotech }\end{array}$ & $\begin{array}{c}\text { Computer, } \\
\text { Electronics } \\
\text { Mfg. } \\
\end{array}$ & $\begin{array}{l}\text { Business } \\
\text { Services } \\
\end{array}$ & \\
\hline \multirow[t]{2}{*}{-3} & -0.599 & -0.002 & -5.149 & -0.033 & -0.671 & 0.000 & -5.175 & -0.031 \\
\hline & 275 & 295 & 30 & 600 & 181 & 191 & 22 & 394 \\
\hline \multirow[t]{2}{*}{-2} & -0.658 & -0.008 & -3.043 & -0.043 & -0.734 & -0.010 & -3.045 & -0.047 \\
\hline & 299 & 331 & 36 & 666 & 195 & 207 & 26 & 428 \\
\hline \multirow[t]{2}{*}{-1} & -0.738 & -0.013 & -1.737 & -0.053 & -0.875 & -0.016 & -2.365 & -0.068 \\
\hline & 326 & 363 & 43 & 732 & 213 & 222 & 28 & 463 \\
\hline \multirow[t]{2}{*}{0} & -0.878 & -0.013 & -4.499 & -0.052 & -1.151 & -0.028 & -6.831 & -0.085 \\
\hline & 427 & 480 & 64 & 971 & 257 & 262 & 37 & 556 \\
\hline \multirow[t]{2}{*}{1} & -1.197 & -0.005 & -6.407 & -0.056 & -1.433 & -0.014 & -6.868 & -0.081 \\
\hline & 388 & 445 & 60 & 893 & 240 & 259 & 37 & 536 \\
\hline \multirow[t]{2}{*}{2} & -1.443 & 0.008 & -6.593 & -0.057 & -1.615 & 0.001 & -6.811 & -0.071 \\
\hline & 343 & 410 & 57 & 810 & 225 & 254 & 37 & 516 \\
\hline \multirow[t]{2}{*}{3} & -1.752 & 0.004 & -6.864 & -0.071 & -1.989 & 0.003 & -6.913 & -0.088 \\
\hline & 300 & 360 & 49 & 709 & 202 & 241 & 34 & 477 \\
\hline \multirow[t]{2}{*}{ Total } & -0.878 & -0.003 & -5.017 & -0.052 & -0.985 & -0.010 & -5.956 & -0.068 \\
\hline & 2,358 & 2,684 & 339 & 5,381 & 1,513 & 1,636 & 221 & 3,370 \\
\hline
\end{tabular}

${ }^{a} \mathrm{R} \& \mathrm{D}$ intensity is R\&D expense scaled by sales and adjusted by subtracting the median R\&D intensity for non-supplier, nonalliance firms in the same 3 digit SIC and year.

Table 5 summarizes R\&D intensity around the alliance. For all firms entering research alliances, R\&D intensity is substantially higher than the benchmark both before and after the alliance, and the overall R\&D intensity does not significantly decrease after the research alliance announcements. For pharmaceutical and biotech firms, high R\&D intensity continues even after announcing research alliances. These results are consistent with Datamonitor's (2007) industry analysis which states that research-intensive biotech firms often seek to speed up an extended development process and not necessarily to reduce costs.

For firms entering marketing alliances, $R \& D$ intensity is generally below the benchmark, although the difference is not substantial for computer and electronics manufacturing firms. R\&D intensity decreases significantly after marketing alliance announcements for pharmaceutical and biotech firms $(\mathrm{p}<0.01$, Kruskal-Wallis test), but does not change for computer and electronics manufacturing firms. Thus, there is some evidence firms entering marketing alliances do so to reduce R\&D costs. Again, the results for null hypotheses $2,2 \mathrm{a}$, and $2 \mathrm{~b}$ are mixed. 
Table 5

Median R\&D Intensity ${ }^{\mathrm{a}}$ around the First Year of Announced Research and Marketing Alliances (with numbers of observations for each industry and year)

\begin{tabular}{|c|c|c|c|c|c|c|}
\hline \multirow{2}{*}{ Year } & \multicolumn{3}{|c|}{ Research Alliances } & \multicolumn{3}{|c|}{ Marketing Alliances } \\
\hline & \multicolumn{2}{|c|}{ Industry } & \multirow[b]{2}{*}{ Total } & \multicolumn{2}{|c|}{ Industry } & \multirow[b]{2}{*}{ Total } \\
\hline $\begin{array}{c}\text { Relative to } \\
\text { Start (0) of } \\
\text { Alliance }\end{array}$ & $\begin{array}{c}\text { Pharma. and } \\
\text { Biotech }\end{array}$ & $\begin{array}{c}\text { Computer, } \\
\text { Electronics } \\
\text { Mfg. }\end{array}$ & & $\begin{array}{l}\text { Pharma. and } \\
\text { Biotech }\end{array}$ & $\begin{array}{c}\text { Computer, } \\
\text { Electronics } \\
\text { Mfg. }\end{array}$ & \\
\hline \multirow[t]{2}{*}{-3} & 1.371 & 0.010 & 0.576 & -0.056 & -0.011 & -0.024 \\
\hline & 28 & 9 & 37 & 11 & 12 & 23 \\
\hline \multirow[t]{2}{*}{-2} & 1.113 & 0.068 & 0.278 & 0.259 & 0.007 & 0.010 \\
\hline & 33 & 15 & 48 & 15 & 15 & 30 \\
\hline \multirow[t]{2}{*}{-1} & 0.632 & 0.066 & 0.258 & -0.113 & -0.025 & -0.035 \\
\hline & 40 & 15 & 55 & 20 & 17 & 37 \\
\hline \multirow[t]{2}{*}{0} & 0.621 & 0.085 & 0.254 & -0.155 & -0.017 & -0.040 \\
\hline & 51 & 17 & 68 & 24 & 17 & 41 \\
\hline \multirow[t]{2}{*}{1} & 1.414 & 0.077 & 0.274 & -0.228 & -0.010 & -0.032 \\
\hline & 49 & 17 & 66 & 24 & 18 & 42 \\
\hline \multirow[t]{2}{*}{2} & 1.055 & 0.089 & 0.283 & -0.317 & 0.006 & -0.009 \\
\hline & 44 & 16 & 60 & 22 & 16 & 38 \\
\hline \multirow[t]{2}{*}{3} & 0.137 & 0.039 & 0.072 & -0.405 & -0.007 & -0.045 \\
\hline & 39 & 13 & 52 & 21 & 16 & 37 \\
\hline \multirow[t]{2}{*}{ Total } & 0.843 & 0.073 & 0.259 & -0.138 & -0.007 & -0.026 \\
\hline & 284 & 102 & 386 & 137 & 111 & 248 \\
\hline
\end{tabular}

${ }^{a} \mathrm{R} \& \mathrm{D}$ intensity is R\&D expense scaled by sales and adjusted by subtracting the median R\&D intensity for non-supplier, nonalliance firms in the same 3 digit SIC and year.

\section{Multivariate analysis of the effect of partnerships on firm performance}

Hagedoorn and Schakenraad (1994) present a model of partnership performance where regional and industry factors influence company structure, which then influences firms propensity to enter partnerships, and the propensity to enter partnerships, firm structure, and regional and industry factors ultimately influence economic performance. Thus, we control for firms' propensity to engage in major customer relationships, research, or marketing alliances by first computing propensity scores and then including those scores as controls in subsequent regressions (e.g., Rosenbaum and Rubin, 1983; Wooldridge 2003).

To predict the propensity of firms to enter partnerships based on firm and industry characteristics, we compute firm-specific propensity scores using the logit models shown in Table 6 and as follows:

$\operatorname{Pr}($ Partnering $)=\mathrm{b}_{0}+\mathrm{b}_{1}$ Adjusted_Operating_ROS

$+\mathrm{b}_{2}$ Median_Industry_Operating ROS $+\mathrm{b}_{3}$ Size

$+\mathrm{b}_{4}$ Business_Segment_Count $+\mathrm{b}_{5}$ Industry_Concentration

$+\mathrm{b}_{6}$ Sales_Growth $+\mathrm{b}_{7}$ Firm_Age $+\mathrm{b}_{8}$ Survivor $+\mathrm{e}$.

The results in Tables 2 and 3 indicate partnering firms perform better than non-partnering firms even before initiating partnerships. We therefore include two broad firm performance measures: 1) Adjusted_Operating_ROS (operating income divided by sales; adjusted by median industry operating ROS for non-supplier, non-alliance firms) and 2) Sales_Growth (sales divided by prior year sales).

Larger, older, more complex high tech firms may be more likely to engage in partnering, since they are more likely to have proven products or established reputations. Prior research also indicates younger firms may benefit differently than larger firms from partnerships (e.g., Stuart et al. 1999, Haussler, 2006). As a result, we also include three measures of firm size and complexity: 1) Size, defined as the log of sales, 2) Firm_Age, defined as the number of years since the first year financial data was available on Compustat, and 3) Business_Segment_Count, the number of different business segments identified in the Compustat Segments file. 
Since prior research suggests industry characteristics affect the propensity to engage in partnerships (e.g., Hagedoorn and Schakenraad, 1994), we specifically include two industry measures: 1) Median_Industry_Operating_ROS (the median value for the 3 digit SIC for each year for those firms that do not report interfirm partnerships) and 2) Industry_Concentration (ratio of the sales of the largest four firms in the 3 digit SIC to total sales for that industry each year). We also include dummy variables to control for general industry characteristics. Finally, we include a dummy variable to indicate whether or not that firm was a survivor as discussed earlier. Column 1 in Table 6 shows industry characteristics significantly influence the propensity for firms to engage in major customer relationships. Somewhat surprisingly, older firms are less likely to engage in major customer relationships after controlling for other firm and industry characteristics. Column 2 in Table 6 shows industry performance is significantly positively related to the propensity to engage in research alliances. Research alliance companies tend to be younger firms with fewer business segments. Column 3 in Table 6 shows industry characteristics also influence the propensity to engage in marketing alliances. Marketing alliance firms tend to be larger and faster growing, but younger than other firms in the sample. Survivor firms are significantly more likely to engage in all three interfirm partnerships.

Table 6

Logit Models Used to Determine Propensity Scores for Period between 1988 and First Reported Major Customer Relationship or Announced Alliance

\begin{tabular}{|c|c|c|c|}
\hline & $\begin{array}{c}\text { (1) } \\
\text { Supplier }_{\text {it }}\end{array}$ & $\begin{array}{c}(2) \\
\text { res_co }{ }_{\text {it }}\end{array}$ & $\begin{array}{c}(3) \\
\text { mkt_co } \\
\text { it }\end{array}$ \\
\hline Adjusted_Operating_ROS $S_{i t}$ & $\begin{array}{c}0.011 \\
(3.94)^{* * *}\end{array}$ & $\begin{array}{c}-0.010 \\
(1.02)\end{array}$ & $\begin{array}{c}-0.028 \\
(2.20)^{* *}\end{array}$ \\
\hline Median_Industry_Operating_ROS $S_{i t}$ & $\begin{array}{c}0.674 \\
(20.04)^{* * *}\end{array}$ & $\begin{array}{c}1.091 \\
(4.36)^{* * *}\end{array}$ & $\begin{array}{c}1.283 \\
(3.07)^{* * * *}\end{array}$ \\
\hline Size $_{i t}$ & $\begin{array}{c}-0.004 \\
(0.26)\end{array}$ & $\begin{array}{c}0.101 \\
(1.71)^{*}\end{array}$ & $\begin{array}{c}0.234 \\
(3.22)^{* * *}\end{array}$ \\
\hline Business_Segment_Count $_{i t}$ & $\begin{array}{l}0.035 \\
(0.40)\end{array}$ & $\begin{array}{c}-1.417 \\
(2.46)^{* *}\end{array}$ & $\begin{array}{c}-1.383 \\
(2.01)^{* *}\end{array}$ \\
\hline Industry_Concentration $_{i t}$ & $\begin{array}{c}2.185 \\
(3.96)^{* * *}\end{array}$ & $\begin{array}{l}3.880 \\
(1.38)\end{array}$ & $\begin{array}{c}17.089 \\
(3.58)^{* * *}\end{array}$ \\
\hline Sales_Growth $_{i t}$ & $\begin{array}{r}-0.023 \\
(1.12)\end{array}$ & $\begin{array}{r}-0.070 \\
(0.91)\end{array}$ & $\begin{array}{c}0.154 \\
(2.02)^{* *}\end{array}$ \\
\hline Firm_Age $_{i t}$ & $\begin{array}{c}-0.010 \\
(2.45)^{* *}\end{array}$ & $\begin{array}{c}-0.097 \\
(4.26) * * *\end{array}$ & $\begin{array}{l}-0.038 \\
(1.73)^{*}\end{array}$ \\
\hline Survivor $_{i}$ & $\begin{array}{c}2.302 \\
(33.14)^{* * *}\end{array}$ & $\begin{array}{c}1.379 \\
(5.59)^{* * *}\end{array}$ & $\begin{array}{c}0.803 \\
(2.66)^{* * *}\end{array}$ \\
\hline Constant & $\begin{array}{l}-0.368 \\
(1.81)^{*}\end{array}$ & $\begin{array}{c}-4.336 \\
(4.08)^{* * *}\end{array}$ & $\begin{array}{c}-10.486 \\
(5.83)^{* * *}\end{array}$ \\
\hline Observations & 6198 & 5930 & 5765 \\
\hline Pseudo R2 & 0.22 & 0.18 & 0.13 \\
\hline
\end{tabular}

Absolute value of $\mathrm{z}$ statistics in parentheses

* significant at $10 \%$; ** significant at $5 \%$; *** significant at $1 \%$

Industry (3 digit SIC) controls included but not reported

supplier = 1 if firm reported major customer relationship at any time during 1988 to 2004, 0 otherwise; res_co = 1 if firm announced research alliance at any time during 1988 to 2004, 0 otherwise; mkt_co $=1$ if firm announced marketing alliance at any time during 1988 to 2004, 0 otherwise; Adjusted_Operating_ROS = firm operating ROS minus industry median operating ROS (Compustat item 13 divided by item 12); Median_Industry_Operating_ROS = industry median operating ROS (Compustat item 13 divided by item 12); Size = natural log of sales (Compustat item 12); Business_Segment_Count = natural log of the number of segments from Compustat Segments; Industry_Concentration = four firm concentration ratio for 3 digit SIC each year; Sales_Growth $=$ sales in year t divided by sales in t-1; Firm_Age = number of years since first Compustat entry; Survivor $=$ 1 if firm data available on Compustat for all years between first public year and 2005; i indicates firm, $t$ indicates year.

\section{Operating ROA performance}

Table 7 examines the impact of partnerships on operating ROA. We begin with the premise that each firm's performance is substantially determined by its prior performance and size. We then examine whether performance relative to previous performance is higher during the years that firms report major customer relationships or within 3 
years after they announce alliances. We control for firm size, since Gomes-Casseres (1997) and Alvarez and Barney (2001) document a relationship between firm size and partnership benefits. We control for selection bias with the propensity scores from the models shown in Table 6 . We test the following model:

$$
\begin{aligned}
O p_{-} R O A_{i t}=b_{0}+ & b_{1} O P_{-} R O A_{i t-I}+b_{2} \text { Size }_{i t}+b_{3} I_{-} I_{C R}+b_{4} \text { In_Research }_{i t} \\
& +b_{5} \text { In_Marketing_Alliance }{ }_{i t}+b_{6} \operatorname{Pr}(\text { Supplier })_{i}+b_{7} \operatorname{Pr}(\text { Research })_{i} \\
& +b_{8} \operatorname{Pr}(\text { Marketing })_{i}+e_{i t}
\end{aligned}
$$

We also consider interaction terms to examine the joint effect of both major customer relationships and alliances:

$$
\begin{aligned}
& O p_{-} R O A_{i t}=b_{0}+b_{1} O p_{-} R O A_{i t-1}+b_{2} S_{i z e}+b_{3} I_{-} C R_{i t}+b_{4} I n_{-} R_{e s e a r c h}{ }_{i t} \\
& +b_{5} \text { In_Marketing }{ }_{i t}+b_{6} I I_{-} C R_{i t} x \text { In_Research }{ }_{i t}+b_{7} I I_{-} C R_{i t} x \text { In_Marketing }{ }_{i t} \\
& +b_{8} \operatorname{Pr}(\text { Supplier })_{i}+b_{9} \operatorname{Pr}(\text { Research })_{i}+b_{10} \operatorname{Pr}(\text { Marketing })_{i}+e_{i t}
\end{aligned}
$$

Where: $O p R O A=$ operating income before depreciation (Compustat item 13) divided by total assets (Compustat item 6) and adjusted by subtracting the annual industry median operating ROA for non-supplier, non-alliance firms; Size $=$ natural log of sales (Compustat item 12); In_CR=1 if firm reports major customer relationship that year, 0 otherwise; In_Research $=1$ if firm announced research alliance within the previous three years, 0 otherwise; In_Marketing $=1$ if firm announced marketing alliance within the previous three years, 0 otherwise; $\operatorname{Pr}(\operatorname{Supplier})=$ propensity to enter major customer relationship from Table 6 , column $1 ; \operatorname{Pr}($ Research $)=$ propensity to announce research alliance from Table 6, column 2; $\operatorname{Pr}($ Marketing $)=$ propensity to announce marketing alliance from Table 6, column 3; In_CR $x$ In_Research = interaction term measuring the joint impact of both a major customer relationship and research alliance; In_CR $x$ In_Marketing = interaction term measuring the joint impact of both a major customer relationship and marketing alliance.

Table 7 presents the regression estimates of Equations 2a and 2b. As expected, current performance is related to prior performance and size. Of interest, performance is significantly higher during major customer relationships, but lower during both research and marketing alliances. We note a strong relation between the supplier propensity score and operating performance, indicating firms that enter customer relationships already perform better on average than other firms in the sample. Performance further improves during the partnership. Univariate results in Table 3 suggest both research and marketing firms improved performance after the alliance announcement. The multivariate results in Table 7 suggest otherwise. Firms in the pharmaceutical and biotech industry perform worse during research alliances and firms in the computer and electronics manufacturing industry perform worse during marketing alliances. Overall, these results contravene null hypothesis 1 but confirm hypotheses 2, 2a, and 2b.

In Column 2 of Table 7, in_cr $x$ in_marketing is significantly positive, suggesting some synergy between major customer relationships and marketing alliances. Overall, though, there is little to suggest substantial synergies, generally confirming null hypothesis 3 .

$R \& D$ Intensity performance

To better understand the impact of partnerships, we also examine R\&D intensity, since R\&D is so vital for many high tech firms. In Table 8, we again use Equations 2a and $2 \mathrm{~b}$ but substitute adjusted R\&D intensity measures for the operating ROA performance measures. We first note firms with greater propensity to enter major customer relationships have significantly lower $R \& D$ intensity and $R \& D$ intensity decreases while firms are in those relationships. With results in Table 7, these suggest firms leverage their customer relationships to become more efficient.

R\&D intensity does not increase in research alliances after controlling for size and the propensity to enter such alliances. Similarly, R\&D intensity does not increase during marketing alliances and those firms have substantially lower levels of R\&D intensity prior to the alliance. In Column 2, the interaction terms indicate firms in both major customer relationships and research alliances also increase R\&D intensity, suggesting these firms' major customers may use this relationship to outsource R\&D. 
Table 7

Regression Tests of Effect of Major Customer Relationships and Alliances on Operating Return on Assets (ROA) ${ }^{\text {a }}$

\begin{tabular}{|c|c|c|c|c|}
\hline & $\begin{array}{c}(1) \\
\text { op_roa } \\
\text { it }\end{array}$ & $\begin{array}{c}(2) \\
\text { op_roa } \\
\text { it }\end{array}$ & $\begin{array}{c}\text { Pharmaceuticals } \\
\text { and Biotech } \\
\text { op_roa }\end{array}$ & $\begin{array}{c}\text { Computer, } \\
\text { Electronics } \\
\text { Manufacturing } \text { op_roa }_{\text {it }} \\
\end{array}$ \\
\hline$O p_{-} R O A_{i t-1}$ & $\begin{array}{c}0.551 \\
(34.16)^{* * *}\end{array}$ & $\begin{array}{c}0.551 \\
(34.14)^{* * *}\end{array}$ & $\begin{array}{c}0.509 \\
(21.78)^{* * *}\end{array}$ & $\begin{array}{c}0.585 \\
(27.50)^{* * *}\end{array}$ \\
\hline Size $_{i t}$ & $\begin{array}{c}0.048 \\
(25.58)^{* * *}\end{array}$ & $\begin{array}{c}0.048 \\
(25.57)^{* * *}\end{array}$ & $\begin{array}{c}0.056 \\
(20.06)^{* * *}\end{array}$ & $\begin{array}{c}0.040 \\
(15.95)^{* * *}\end{array}$ \\
\hline$I n_{-} C R_{i t}$ & $\begin{array}{c}0.021 \\
(2.50)^{* *}\end{array}$ & $\begin{array}{c}0.019 \\
(2.24)^{* *}\end{array}$ & $\begin{array}{c}0.034 \\
(2.60) * * *\end{array}$ & $\begin{array}{c}0.020 \\
(1.91)^{*}\end{array}$ \\
\hline In_Research ${ }_{i t}$ & $\begin{array}{c}-0.029 \\
(2.30)^{* *}\end{array}$ & $\begin{array}{l}-0.033 \\
(1.80)^{*}\end{array}$ & $\begin{array}{c}-0.034 \\
(2.27)^{* *}\end{array}$ & $\begin{array}{c}-0.019 \\
(0.97)\end{array}$ \\
\hline In_Marketing $_{\text {it }}$ & $\begin{array}{l}-0.041 \\
(2.39)^{* *}\end{array}$ & $\begin{array}{l}-0.063 \\
(2.46)^{* *}\end{array}$ & $\begin{array}{l}-0.027 \\
(1.20)\end{array}$ & $\begin{array}{c}-0.062 \\
(2.65) * * *\end{array}$ \\
\hline In_CR $R_{i t} x$ In_Research ${ }_{i t}$ & & $\begin{array}{l}0.012 \\
(0.51)\end{array}$ & & \\
\hline In_CR $_{i t} x$ In_Marketing ${ }_{i t}$ & & $\begin{array}{c}0.056 \\
(1.76)^{*}\end{array}$ & & \\
\hline $\operatorname{Pr}\left(\right.$ Supplier $_{i}$ & $\begin{array}{c}0.032 \\
(2.22)^{* *}\end{array}$ & $\begin{array}{c}0.033 \\
(2.28)^{* *}\end{array}$ & $\begin{array}{c}0.058 \\
(2.09)^{* *}\end{array}$ & $\begin{array}{c}0.110 \\
(5.97)^{* * *}\end{array}$ \\
\hline $\operatorname{Pr}(\text { Research })_{i}$ & $\begin{array}{r}-0.371 \\
(1.63)\end{array}$ & $\begin{array}{r}-0.370 \\
(1.62)\end{array}$ & $\begin{array}{l}-0.203 \\
(0.67)\end{array}$ & $\begin{array}{r}-0.283 \\
(0.81)\end{array}$ \\
\hline $\operatorname{Pr}(\text { Marketing })_{i}$ & $\begin{array}{l}0.229 \\
(0.60)\end{array}$ & $\begin{array}{l}0.232 \\
(0.61)\end{array}$ & $\begin{array}{c}1.761 \\
(2.93)^{* * * *}\end{array}$ & $\begin{array}{r}-0.499 \\
(1.07)\end{array}$ \\
\hline Constant & $\begin{array}{c}-0.119 \\
(10.54)^{* * *}\end{array}$ & $\begin{array}{c}-0.119 \\
(10.55)^{* * *}\end{array}$ & $\begin{array}{c}-0.174 \\
(9.90)^{* * *}\end{array}$ & $\begin{array}{c}-0.282 \\
(14.69)^{* * *}\end{array}$ \\
\hline $\begin{array}{l}\text { Observations } \\
\text { Adj R2 }\end{array}$ & $\begin{array}{c}10571 \\
0.56\end{array}$ & $\begin{array}{c}10571 \\
0.56\end{array}$ & $\begin{array}{l}5014 \\
0.57\end{array}$ & $\begin{array}{r}5557 \\
0.55\end{array}$ \\
\hline
\end{tabular}

Robust t statistics in parentheses

$*$ significant at $10 \% ; * *$ significant at $5 \%$; *** significant at $1 \%$

Industry and Year controls included but not reported

$O p \_R O A=$ operating return on assets (Compustat item 13 divided by item 6); Size = natural log of sales (Compustat item 12);

$I n \_C R=1$ if firm in major customer relationship, 0 otherwise; in_research $=1$ if firm within 3 years after announcement of research alliance, 0 otherwise; In_Marketing $=1$ if firm within 3 years after announcement of marketing alliance, 0 otherwise In_CR $x$ In_Research $=$ interaction term; In_CR $x$ In_Marketing $=$ interaction term; $\operatorname{Pr}($ Supplier $)=$ propensity for supplier determined from Model 1 in Table 6; $\operatorname{Pr}($ Research $)=$ propensity for company to enter research alliance from model 2 in Table 6; $\operatorname{Pr}($ Marketing $)=$ propensity for company to enter marketing alliance from Model 3 in Table 6; i indicates firm, t indicates year.

The results for pharmaceutical and biotech industry firms are generally similar to the overall results in column (1) of Table 8, although R\&D intensity does increase during research alliances. For computer and electronics manufacturing firms, $R \& D$ intensity increases in both types of alliances. Again, there is little evidence alliances support cost reduction efforts.

\section{Market reactions to alliance announcements}

Finally, we test whether the market reaction to the alliance announcements in our sample is consistent with prior research that documents a positive market reaction to alliances. Of note, no previous study has tested whether a major customer relationship or other operational constraint affects the market's reaction to an alliance announcement.

We test the market reaction to the announcement of the alliances and acquisitions using event study methodology. Following Allen and Phillips (2000), we employed a 175-day estimation period from 200 days to 25 prior to the announcement date. Since the alliance announcements are often made several days after the actual agreement, it is possible the market reacts prior to the publication in the Wall Street Journal. Thus, we report CARs 
and average abnormal returns over a 21 -day $(-10,+10)$ event window as well as over a shorter 4-day window $(-2$, +1 ). We estimate abnormal returns as the ordinary least squares residuals from a single-factor market model using a value-weighted market portfolio. The reported significance tests are based on the standardized residuals method (Patell, 1976) for the CARs and standardized cross-sectional method (Boehmer et al., 1991) for the average abnormal returns.

Table 9 presents results from the event study using the approximately 80 percent (229 of 288) announcements with available security return data over the estimation window. The CARs for the total sample are 6 percent, significant at the 1 percent level, for both event windows. The abnormal returns are 0.3 percent for the longer window and 1.4 percent for the shorter window, again both significant at the 1 percent level. Approximately 64 percent of the CARs are positive in the shorter window, which is also significant at the 1 percent level.

Table 8

Regression Tests of Effect of Major Customer Relationships and Alliances on R\&D Intensity (R\&D/Sales) $)^{\mathrm{a}}$

\begin{tabular}{|c|c|c|c|c|}
\hline & $\begin{array}{c}\text { (1) } \\
\text { rd_sls } \text { sit }_{\text {it }}\end{array}$ & $\begin{array}{c}(2) \\
\text { rd_sls } \\
\text { it }\end{array}$ & $\begin{array}{c}\text { Pharmaceuticals } \\
\text { and Biotech } \\
\text { rd_sls } \\
\text { it }\end{array}$ & $\begin{array}{c}\text { Computer, } \\
\text { Electronics } \\
\text { Manufacturing } \\
\text { rd_sls }_{\text {it }} \\
\end{array}$ \\
\hline rd_sls $\mathrm{it}-1_{1}$ & $\begin{array}{c}0.480 \\
(20.77)^{* * *}\end{array}$ & $\begin{array}{c}0.480 \\
(20.76)^{* * *}\end{array}$ & $\begin{array}{c}0.441 \\
(17.98)^{* * * *}\end{array}$ & $\begin{array}{c}0.477 \\
(6.83)^{* * *}\end{array}$ \\
\hline size $_{\text {it }}$ & $\begin{array}{c}-0.681 \\
(18.03)^{* * *}\end{array}$ & $\begin{array}{c}-0.681 \\
(18.03)^{* * * *}\end{array}$ & $\begin{array}{c}-1.035 \\
(17.49)^{* * *}\end{array}$ & $\begin{array}{c}-0.231 \\
(5.55)^{* * *}\end{array}$ \\
\hline in_cr $r_{i t}$ & $\begin{array}{c}-0.469 \\
(3.38) * * *\end{array}$ & $\begin{array}{c}-0.526 \\
(3.75)^{* * *}\end{array}$ & $\begin{array}{c}-0.593 \\
(2.22)^{* *}\end{array}$ & $\begin{array}{c}-0.256 \\
(3.02)^{* * *}\end{array}$ \\
\hline in_research ${ }_{\text {it }}$ & $\begin{array}{l}0.513 \\
(1.49)\end{array}$ & $\begin{array}{c}-0.264 \\
(0.78)\end{array}$ & $\begin{array}{c}0.713 \\
(1.66)^{*}\end{array}$ & $\begin{array}{c}0.188 \\
(3.35)^{* * *}\end{array}$ \\
\hline in_marketing ${ }_{\text {it }}$ & $\begin{array}{l}0.225 \\
(1.18)\end{array}$ & $\begin{array}{l}0.375 \\
(1.55)\end{array}$ & $\begin{array}{l}0.453 \\
(1.42)\end{array}$ & $\begin{array}{c}0.255 \\
(3.69) * * *\end{array}$ \\
\hline in_cr ${ }_{i t} x$ in_research ${ }_{i t}$ & & $\begin{array}{c}1.649 \\
(2.40)^{* *}\end{array}$ & & \\
\hline in_cr $r_{i t} \mathrm{x}$ in_marketing $\mathrm{it}_{\mathrm{it}}$ & & $\begin{array}{l}-0.116 \\
(0.33)\end{array}$ & & \\
\hline $\operatorname{Pr}\left(\right.$ supplier $_{\mathrm{i}}$ & $\begin{array}{c}-1.001 \\
(4.55)^{* * * *}\end{array}$ & $\begin{array}{c}-0.978 \\
(4.46)^{* * *}\end{array}$ & $\begin{array}{c}-3.126 \\
(5.78)^{* * *}\end{array}$ & $\begin{array}{l}-0.259 \\
(1.56)\end{array}$ \\
\hline $\operatorname{Pr}(\text { res_co })_{\mathrm{i}}$ & $\begin{array}{c}10.490 \\
(2.85)^{* * *}\end{array}$ & $\begin{array}{c}10.773 \\
(2.93)^{* * *}\end{array}$ & $\begin{array}{c}26.043 \\
(4.11)^{* * *}\end{array}$ & $\begin{array}{c}-7.279 \\
(3.67) * * *\end{array}$ \\
\hline $\operatorname{Pr}(\text { mkt_co })_{\mathrm{i}}$ & $\begin{array}{c}19.979 \\
(2.67) * * *\end{array}$ & $\begin{array}{c}19.784 \\
(2.64) * * *\end{array}$ & $\begin{array}{l}10.745 \\
(0.81)\end{array}$ & $\begin{array}{c}25.569 \\
(4.07)^{* * *}\end{array}$ \\
\hline Constant & $\begin{array}{c}3.077 \\
(13.17)^{* * *}\end{array}$ & $\begin{array}{c}3.077 \\
(13.17)^{* * *}\end{array}$ & $\begin{array}{c}5.077 \\
(13.47)^{* * *}\end{array}$ & $\begin{array}{c}1.205 \\
(4.83)^{* * *}\end{array}$ \\
\hline $\begin{array}{l}\text { Observations } \\
\text { Adj R2 }\end{array}$ & $\begin{array}{c}10571 \\
0.43\end{array}$ & $\begin{array}{c}10571 \\
0.43\end{array}$ & $\begin{array}{l}5014 \\
0.45\end{array}$ & $\begin{array}{l}5557 \\
0.36\end{array}$ \\
\hline
\end{tabular}

Robust $\mathrm{t}$ statistics in parentheses

* significant at $10 \% ; * *$ significant at $5 \%$; *** significant at $1 \%$

Industry and Year controls included but not reported

rd_sls = R\&D expense (Compustat item 46) divided by sales (item 12) and adjusted by subtracting median rd_sls value for nonsupplier, non-alliance firms for the same industry (3 digit SIC) and year; size = natural log of sales (Compustat item 12); in_cr = 1 if firm in major customer relationship, 0 otherwise; in_research $=1$ if firm within 3 years after announcement of research alliance, 0 otherwise; in_marketing $=1$ if firm within 3 years after announcement of marketing alliance, 0 otherwise; in_cr $\mathrm{x}$ in_research = interaction term; in_cr $\mathrm{x}$ in_marketing $=$ interaction term; $\operatorname{Pr}($ supplier $)=$ propensity for supplier determined from Model 1; $\operatorname{Pr}($ res_co $)=$ propensity for company to enter research alliance; $\operatorname{Pr}($ mkt_co $)$ = propensity for company to enter marketing alliance; i indicates firm, $t$ indicates year. 
Table 9

Cumulative and Mean Abnormal Returns by Industry, Major Customer Relationship Status, and Alliance Type

\begin{tabular}{|c|c|c|c|c|c|c|}
\hline & \multirow[b]{2}{*}{$\mathbf{N}$} & \multicolumn{2}{|c|}{ CAR Event Windows } & \multicolumn{2}{|c|}{ Mean AR Event Windows } & \multirow[b]{2}{*}{$+/-$} \\
\hline & & $(-10,+10)$ & $(-2,1)$ & $(-10,+10)$ & $(-2,1)$ & \\
\hline Total sample & 229 & $0.06(4.64)^{* * *}$ & $0.06(3.98)^{* * *}$ & $0.003(2.59)^{* * *}$ & $0.014(2.55)^{* * *}$ & $147 / 82 * * *$ \\
\hline \multicolumn{7}{|l|}{ By Industry classification } \\
\hline Pharmaceuticals/Biotech (SIC 28) & 164 & $0.07(4.37)^{* * *}$ & $0.06(2.01)^{* *}$ & $0.003(2.30)^{* *}$ & $0.011(1.60)^{*}$ & $107 / 57 * * *$ \\
\hline Computer equipment and Electronics Manufacturing (SIC 35 and 36) & 65 & $0.06(2.37)^{* * *}$ & $0.08(3.96)^{* * *}$ & $0.004(1.02)$ & $0.018(1.64)$ & $40 / 25 * *$ \\
\hline \multicolumn{7}{|l|}{ By major customer relationship } \\
\hline Pre-major customer relation & 116 & $0.05(3.53) * * *$ & $0.05(3.57) * * *$ & $0.002(1.87)^{* *}$ & $0.013(2.10)^{* *}$ & $75 / 41 * * *$ \\
\hline During major customer relation & 92 & $0.07(2.68) * * *$ & $0.09(2.54)^{* * *}$ & $0.004(1.57)^{*}$ & $0.016(1.64)^{*}$ & $58 / 34 * * *$ \\
\hline \multicolumn{7}{|l|}{ By type of alliancelacquisition } \\
\hline Research alliance & 122 & $0.05(3.03)^{* * *}$ & $0.04(1.74)^{* *}$ & $0.002(1.77)^{* *}$ & $0.008(1.13)$ & $71 / 51 * *$ \\
\hline Marketing alliance & 62 & $0.03(1.78)^{* *}$ & $0.03(2.96)^{* * *}$ & $0.001(1.16)$ & $0.014(1.77)^{* *}$ & $43 / 19 * * *$ \\
\hline Acquisition & 45 & $0.13(3.37)^{* * *}$ & $0.16(2.62) * * *$ & $0.022(1.39)^{*}$ & $0.014(1.63)^{*}$ & $33 / 12 * * *$ \\
\hline \multicolumn{7}{|l|}{ By type of alliance and customer status } \\
\hline Research alliance pre-major customer relationship & 74 & $0.08(3.63)^{* * *}$ & $0.06(2.49)^{* * *}$ & $0.004(1.61)^{*}$ & $0.014(1.44)^{*}$ & $46 / 28 * *$ \\
\hline Research alliance during major customer relationship & 40 & $0.01(0.18)$ & $0.04(0.51)$ & $0.000(0.16)$ & $0.008(0.35)$ & $22 / 18$ \\
\hline Marketing alliance pre-major customer relationship & 40 & $0.00(0.95)$ & $0.03(2.26)^{* *}$ & $0.000(0.69)$ & $0.009(1.40)^{*}$ & $28 / 12 * *$ \\
\hline Marketing alliance during major customer relationship & 14 & $0.10(1.61)^{*}$ & $0.07(2.37)^{* *}$ & $0.005(0.68)$ & $0.025(1.00)$ & $8 / 6$ \\
\hline
\end{tabular}

* significant at 10\%; ** significant at 5\%; *** significant at 1\%; Sample consists of 104 firms in the sample that participated in 229 alliance or acquisition announcements.

Abnormal returns are calculated using the market model with CRSP value-weighted returns estimated over the period from 200 days to 25 days prior to the announcement.

z statistics for CAR in parentheses are calculated from the standardized abnormal returns following Patell (1976); $t$-statistics for mean AR in parentheses are based on the standardized cross-sectional method. The number of positive and negative CAR values during the $(-2,1)$ window are presented in the last column with significance determined by the generalized sign test. 
We find abnormal returns are generally similar for the two industries and before and during major customer relationships. Since there are relatively few alliance announcements after firms end major customer relationships, we do not report results for that situation. Comparing the market reaction to research versus marketing alliances, the abnormal returns are generally higher for research alliances, although CARs for both are significantly greater than zero. For comparison, the market clearly reacts more strongly to acquisition announcements. The acquisition CARs are 13 percent for the longer window and 16 percent for the shorter window, both significant at the 1 percent level and substantially higher than the corresponding CARs for the alliances.

The market reacts more strongly to research alliance announcements before major customer relationships and to marketing alliance announcements during major customer relationships. Firms generally have similar strategic motives for both major customer relationships and marketing alliances. Firms enter these ventures to expand their market and grow revenues. Thus, it is reasonable to expect the market to react more strongly to marketing alliances during major customer relationships. The strategic motives for research alliances and major customer relationships can differ. Research alliances focus on innovation and new product development, and not the sales of existing products. Thus, it is also reasonable the market reacts more strongly to research alliances before major customer relationships.

In summary, our event study results are consistent with prior research. The market reacts positively to alliance announcements. Our operating performance results suggest, however, that the market may be overestimating future performance.

\section{CONCLUSION}

In this paper, we examine how interfirm partnerships impact firm performance. With a global economy, rapid product cycles, capital constraints and advances in technology, firms seldom possess all the capability necessary to maintain and grow market share. Consequently, firms often rely on a variety of partnerships. Theory suggests firms enter such relationships to improve performance through access to new products, new markets, new capabilities, and more resources. Yet, relatively little is known about the long-term impact of collaborative arrangements such as alliances and major customer relationships.

Our study provides evidence that benefits of interfirm partnerships are industry and type specific. The generally positive market reaction to alliance announcements seems overly optimistic. Only firms in major customer relationships consistently demonstrate significant increases in performance, and those companies already outperformed peers before entering those relationships. Our results provide evidence in support of managers' opinions that collaborative ventures do not always achieve their stated objectives PriceWaterhouseCoopers (2004).

\section{ACKNOWLEDGEMENTS}

We thank workshop participants at the University of Arkansas and participants at the 2007 American Accounting Association Management Accounting Section Mid-Year meeting for helpful comments.

\section{AUTHOR INFORMATION}

Carolyn M. Callahan is the KPMG Distinguished Professor of Accounting and Director of the School of Accountancy at the University of Memphis. She earned her Ph.D. from Michigan State University with a dual emphasis in accounting and finance. Dr. Callahan's research efforts focus on managerial incentives and information transmission in the capital markets. Her work is published in highly ranked academic journals, such as The Accounting Review, Journal of Accounting Research, Contemporary Accounting Research, and Accounting Horizons, among others. Carolyn is a member of several editorial boards, including The Accounting Review and Journal of International Business Studies. E-mail: cmcllhan@memphis.edu (Corresponding author)

Rod E. Smith is currently a professor in the Department of Accountancy, California State University Long Beach College of Business Administration. He received his Ph.D. from the University of California, Irvine. His primary research interests focus on financial and non-financial measures of organizational performance, and the business 
value of information technology. He has published articles in The Accounting Review, The Journal of Information Systems, The International Journal of Accounting Information Systems, and the Journal of Management Accounting Research, among others. E-mail: rsmith5@csulb.edu

Angela Wheeler Spencer is an assistant professor of accounting in the Spears Schools of Business at Oklahoma State University. She earned her Ph.D. from the University of Arkansas-Fayetteville in 2006. She has previous experience in public accounting and is a certified public accountant. She currently teaches financial accounting in the undergraduate and graduate programs at Oklahoma State and her research focuses on off-balance sheet structures, leasing, and alliance activity. Her research has appeared in the The Accounting Review. E-mail: angela.spencer@okstate.edu

\section{REFERENCES}

1. Allen J. and Phillips G. (2000). Corporate equity ownership, strategic alliances and product market relationships. Journal of Finance, 55(6) 791-814.

2. Alvarez S. A. and Barney J.B. (2001). How entrepreneurial firms can benefit from alliances with large partners. Academy of Management Executive, 15(1) 139-148.

3. Arend R.J. and Amit R. (2005). Selection in strategic alliance activity: effects on firm performance in the computing industry. European Management Journal, 23(4) 361-381.

4. Baker G. Gibbons R. and Murphy K.J. (2002). Relational contracts and the theory of the firm. Quarterly Journal of Economics, 117(1) 39-84.

5. Bamford J., and Ernst D. (2002). Measuring alliance performance. McKinsey on Finance, Autumn 6-10.

6. Beckett-Camarata E.J., Camarata M.R., Barker R.T. (1998). Integrating internal and external customer relationships through relationship management: a strategic response to a changing global environment. Journal of Business Research, 41 71-81.

7. Boehmer E. Musumeci J. and Poulsen A.B. (1991). Event-study methodology under conditions of eventinduced variance. Journal of Financial Economics, 30 253-72.

8. Borys B. Jemison D.B. (1989). Hybrid arrangements as strategic alliances: theoretical issues. The Academy of Management Review, 14(2) 234-249.

9. Chan S.H. Kensinger J.W. Keown A.J. and Martin J.D. (1997). Do strategic alliances create value? Journal of Financial Economics, 46 199-221.

10. Chiesa V. and Manzini R. (1998). Organizing for technological collaborations: a managerial perspective. $R \& D$ Management, 28(3) 199-212.

11. Contractor F.J. and Lorange P. (1988), Competition versus cooperation: a benefit/cost framework for choosing between fully-owned investments and cooperative relationships. Management International Review, 28 5-18.

12. Contractor F.J. and Lorange P. (2004). Why should firms cooperate? The strategy and economics basis for cooperative ventures. In Reuer J.J., editor. Strategic Alliances: Theory and Evidence. USA: Oxford University Press.

13. Das S. Sen P.K. and Sengupta S. (1998). Impact of strategic alliances on firm valuation. Academy of Management Journal, 41(1) 27-41.

14. Datamonitor. (2007). Global Pharmaceuticals, Biotechnology \& Life Sciences (Pharmaceuticals). London, UK: Datamonitor.

15. Dekker H. C. (2004). Control of inter-organizational relationships: evidence on appropriation concerns and coordination requirements. Accounting, Organizations and Society, 29 27-49.

16. Dwyer F.R. and Oh S. (1988). A transaction cost perspective on vertical contractual structure and interchannel competitive strategies. Journal of Marketing, 52(2) 21-35.

17. Dwyer F.R. Schurr P.H. and Oh S. (1987). Developing buyer-seller relationships. Journal of Marketing, 51(April) 11-27.

18. Dyer J.H. Kale P. and Singh H. (2004). When to ally and when to acquire. Harvard Business Review, 82(7) 109-115.

19. Eisenhardt K.M. and Schoonhoven C.B. (1996). Resource-based view of strategic alliance formation: strategic and social effects in entrepreneurial firms. Organization Science, 7(2) 136-150. 
20. Financial Accounting Standards Board. (1976). SFAS No. 14: Financial Reporting for Segments of a Business Enterprise. Norwalk, CT: FASB.

21. Financial Accounting Standards Board. (1997). SFAS No. 131 Disclosures About Segments of an Enterprise and Related Information. Norwalk, CT: FASB.

22. Francis J. and Schipper K. (1999). Have financial statements lost their relevance? Journal of Accounting Research, 37(2) 319-52.

23. Gleason K.C. Mathur I. and Wiggins R.A. III. (2003). Evidence on value creation in the financial services industries through the use of joint ventures and strategic alliances. The Financial Review, 38 213-34.

24. Gomes-Casseres B. (1997). Alliance strategies of small firms. Small Business Economics, 9 33-44.

25. Gosman M. Kelly T. Olsson P. and Warfield T. (2004). The profitability and pricing of major customers. Review of Accounting Studies, 9(1) 117-39.

26. Hagedoorn J., and Schakenraad J. (1994). The effect of strategic technology alliances on company performance. Strategic Management Journal, 15 291-309.

27. Harrigan K.R. (1986). Matching vertical integration strategies to competitive conditions. Strategic Management Journal, 7(6) 535-555.

28. Haussler C. (2006). When does partnering create market value? European Management Journal, 24(1) 115.

29. Ittner C. D. Larcker D.F. Nagar V. and Rajan M.V. (1999). Supplier selection, monitoring practices, and firm performance. Journal of Accounting and Public Policy, 18 253-281.

30. Jensen M. (2004). Who gets Wall Street's attention? How alliance announcements and alliance density affect analysts coverage. Strategic Organization, 2(3) 293-312.

31. Kale P. Dyer J.H. and Singh H. (2002). Alliance capability, stock market response, and long-term alliance success: the role of the alliance function. Strategic Management Journal, 23 747-767.

32. Koh H. and Venkatraman N. (1991). Joint-venture formation and stock market reaction: an assessment in the information technology sector. Academy of Management Journal, 34(4) 869-92.

33. Lambert D. M. (2006). Supply chain management. In: Lambert D.M., editor. Supply Chain Management, Processes, Partnerships, and Performance. Sarasota, Fl: Supply Chain Management Institute,

34. Lee Y. Cavusgil S.T. (2006). Enhancing alliance performance: the effects of contractual-based versus relational-based governance. Journal of Business Research, 59 896-905.

35. Marciukaityte D. Roskelley K. and Wang H. (2009). Strategic alliances by financial services firms. Journal of Business Research, 62 1193-1199.

36. McConell J.J. and Nantell T.J. (1985). Corporate combinations and common stock returns: the case of joint ventures. The Journal of Finance, 40(2) 519-36.

37. Mohanram P. and Nanda A. (1998).When do joint ventures create value? Working Paper

38. McCutchen W.W. Jr., and Swamidass P.M. (2004). Motivations for strategic alliances in the pharmaceutical/biotech industry: Some new findings. Journal of High Technology Management Research, 15 197-214.

39. Patell J.M. (1976). Corporate forecasts of earnings per share and stock price behavior; empirical tests. Journal of Accounting Research, 14(2) 246-276.

40. Piachaud B. and Muresan E. (2004). A study of shareholder reaction to technology motivated joint ventures and strategic alliances: strategic and financial perspectives. International Journal of Technology Management, 27(4) 343-56.

41. PriceWaterhouseCoopers (and CFO Research Services). (2004). The CFO's perspective on alliances; growth, risk, and measurement. CFO Publishing Corp,

42. Reuer J. and Leiblein M.J. (2000). Downside risk implications of multinationality and international joint ventures. Academy of Management Journal, 43(2) 203-214.

43. Rosenbaum P.R. and Rubin D.B. (1983). The central role of the propensity score in observational studies for causal effects. Biometrika 70(1) 41-55.

44. Sarkar M.B. Aulakh P.S. Madhok, A. (2009). Process capabilities and value generation in alliance portfolios. Organization Science, 20(3) 583-604.

45. Son M. Hahn M. and Kang H. (2006). Why firms do co-promotions in mature markets? Journal of Business Research, 59 1035-1042.

46. Standard and Poor's. (2001). Industry Surveys: Computer Hardware. New York: Standard and Poor's. 
47. Stuart T. E. Hoang H. and Hybels R.C. (1999). Interorganizational endorsements and the performance of entrepreneurial ventures. Administrative Science Quarterly, 44(2) 315-349.

48. Wilbon A. D. (2002). Predicting survival of high-technology initial public offering firms. Journal of High Technology Management Research, 13 127-141.

49. Wooldridge J. M. (2003). Introductory Econometrics: A Modern Approach, $2^{\text {nd }}$ edition. Mason OH: Thomson South-Western. 